\title{
Self-construal and cultural orientation as predictors for developmental goals: A comparison between Brazilian and German caregivers
}

\author{
Wolfgang Friedlmeier \\ Grand Valley State University, Allendale, Michigan, USA \\ Esther Schäfermeier \\ University of Cologne, Cologne, Germany \\ Vera Vasconcellos \\ State University of Rio de Janeiro, Rio de Janeiro, Brazil \\ Gisela Trommsdorff \\ University of Konstanz, Konstanz, Germany
}

Correspondence should be addressed to Wolfgang Friedlmeier, Department of Psychology. Grand Valley State University, 2117 Au Sable Hall, Allendale, MI 49401, USA.

E-mail: friedlmw@gvsu.edu

This study was supported by a grant of the Deutsche Forschungsgemeinschaft (SFB 511, TP15) as part of the project "Subjective child-rearing theories in cultural perspective" (principal investigators: Prof. Gisela Trommsdorff and Prof. Wolfgang Friedlmeier) and a grant of $\mathrm{CNPq}$ (Conselho Nacional de Pesquisa, Brazil-Porc. $N^{*} 520938 / 96-8$ ) as part of the project "Contextos Infantis de Construção do Conhecimento e Formaçnao da Subjetividade da Crianca e do Educador" (principal investigator: Prof. Vera Vasconcellos). Several research exchanges between the German and Brazilian collaborators were supported by grants of the Deutscher Akademischer Austauschdienst (DAAD) and CAPES.

We are grateful to Gabriella von Lieres, Marian Jimenez, Suzi Oliveria, Christina Bergman, Bettina Wetter, Christina Tzschetzsch, Katrin Steeb, Alexandru Agache, Antje von Suchodeletz, Claudia Catani, Franziska Kärcher, Christina Bergmann, Bettina Wetter, Andrea Kühnel and Antje Müller for their assistance in the German study. We would like to thank Suely de Almeida Batista Dessandre, Ricardo Noleto Teixeira, Minna Gondim Marques. Ana Carolina Monerat Fioravanti, Lilia Vales Domingues, Flávia Maria Cabral de Almeida, Cynthia de Souza Paiva Nascimento, Ana Paula de Castro Cordeiro, Adelaide Alves Dias, Rita de Cassia Gomes, and Vera Lúcia Néri da Silva for their assistance in the Brazilian study. Special thanks go to Christine Smith for her critical comments and improvement of the language of the manuscript. We also thank all the teachers and mothers who participated in this study. Finally, we would like to thank the two anonymous reviewers for their thorough comments on an earlier draft of this manuscript.

Konstanzer Online-Publikations-System (KOPS)

URL: http://www.ub.uni-konstanz.de/kops/volltexte/2008/5945/

URN: http://nbn-resolving.de/urn:nbn:de:bsz:352-opus-59450 
The aim of this study was to investigate caregivers' developmental goals in Brazil and Germany and to explain inter- and intracultural variations in these goals by taking their respective subjective cultural values into account. The main question was whether caregivers' preferences of developmental goals depend on their perception of prevailing norms in the culture or on their personal value preferences. German and Brazilian kindergarten teachers and mothers of 5-year-old children $(N=128)$ participated in the study. They were asked to select and rank the developmental goals based on importance out of a given list of goals. Furthermore, the caregivers' self-construal (SCS) and their normative and evaluative cultural orientation (COS) were assessed. Results yielded culture-specific differences for self-construal, cultural orientation, and preferences of developmental goals. The caregivers' perception of prevailing cultural norms was the best predictor for goal preferences.

Knowledge about parents' goals regarding their child's development is a key in understanding cultural patterns of child-rearing (Harkness \& Super, 1996). Developmental goals represent abilities and characteristics that caregivers want the children to develop (Goodnow \& Collins, 1990; Kornadt \& Trommsdorff, 1984). These goals play an important role in the development of the child as they influence the caregiver's perception and evaluation of the child's behaviour (e.g., McGillicuddy-DeLisi, 1985; Trommsdorff \& Kornadt, 2003) as well as the caregiver's child-rearing behaviour (Goodnow \& Collins, 1990; Holden \& Buck, 2002; Sigel, McGillicuddy-DeLisi, \& Goodnow, 1992).

Classic ethnographical and anthropological studies (e.g., Benedict, 1934; LeVine, 1977; Malinowski, 1966; Mead, 1966; Whiting \& Whiting, 1975) focused on culture and parenting goals. In a similar way, more recent crosscultural studies of developmental goals explain cultural differences by referring to general cultural norms, e.g., individualistic vs. collectivist norms, or contextual variables, such as socioeconomic status and formal education (e.g., Chao, 1995; Harwood, Schölmerich, Ventura-Cook, Schulze, \& Wilson, 1996; Schulze, Harwood, \& Schölmerich, 2001). These studies are consistent with the theoretical approach that conceptualizes parental goals as parts of ethnotheories or subjective belief systems (e.g., Bornstein \& Cote, 2003; Sigel, 1985; Sigel et al., 1992) as well as with the approach of the developmental niche (Super \& Harkness, 1986, 1997).

However, the studies mentioned above show three shortcomings: First, the reference to cultural norms assumes that all caregivers of a cultural group share the same general values. It remains unclear how these general values are manifested in daily practices and how they affect the individual beliefs of caregivers. A more detailed description of cultural background and its effect on individuals is necessary. Second, in addition to a more extensive description, individual representations of such values should be 
tested empirically. Third, almost all studies focus on the perspective of the mother as caregiver. It is assumed that there is general consensus among all caregivers. However, the convergence in values between mothers and teachers is an open empirical question that has rarely been tested.

The main contribution of this study is to extend the explanation of interand intracultural differences of developmental goals by taking specific cultural settings (as related to the general values) and individual differences into account. More specifically, we analysed the effects of caregivers' personal value orientation as well as their recognition of cultural norms on their preferences of developmental goals. Second, we aimed to test intra- and intercultural differences of these relations between professional (kindergarten teachers) and non-professional caregivers (mothers).

\section{Cross-cultural differences in developmental goals}

Cross-cultural research documents significant differences in developmental goals between cultural groups (e.g., Chao, 1995; Harwood, 1992; Kornadt \& Trommsdorff, 1990; New \& Richman, 1996; Rosenthal \& Roer-Strier, 2001; Schwarz, Schäfermeier, \& Trommsdorff, 2005). In individualistic cultures like Germany and the USA (e.g., Anglo American mothers), individualoriented developmental goals like autonomy, independence, self-realization, self-confidence, and self-maximization are preferred by most caregivers (Chao, 1995; Harwood, 1992; Triandis, 2001; Trommsdorff, 1999). The emphasis on individuality in a cultural group may afford specific social goals that organize the social life. It may be important to get along with others, i.e., by tolerating each other, and less important to take the others' needs into account. The value of tolerance (of accepting the other person with his/her own personality and lifestyle) is an important aspect of social competence in individualistic cultures (Friedlmeier, 1995; Oerter \& Oerter, 1995). In contrast, members of collectivist cultures like Puerto Rican (Schulze et al., 2001) or Chinese American mothers (Chao, 1995) stress that the individual person acts as part of the relevant collective (e.g., family). They emphasize group-oriented developmental goals (e.g., co-operation, ability for smooth interaction, sensitivity for others' needs, and responsi-

bility for others). Accordingly, they believe that it is important to foster a good relationship with the child and to teach the child how to respect and to adapt to others.

\section{Cultural characteristics, self-construal and preferences of developmental goals}

Brazil can be seen as a culture in which rather collectivist norms dominate whereas in Germany rather individualistic norms prevail (e.g., Gouveia, de 
Albuquerque, Clemente, \& Espinosa, 2002; Hofstede, 2001; Merritt, 2000). Such dichotomous perspective gives a rough description of differences but is not sufficient to explain the differences of developmental goals (Suizzo, 2004). In the following study, we extend the arguments for cultural differences and their impact on caregivers' preferences of developmental goals.

Individualistic cultures are mostly wealthy and dependence on adult offspring is less important. Germany is a wealthy industrialized and modern European democratic country characterized by postmodern values, a strong focus on rational-legal authority (Inglehart, 1997), and a Western background (i.e., a general worldview based on a common history from the classical ancient world, through Christianity, enlightenment, industrialization, and modernization).

Collectivist cultures are less wealthy, are mostly rural agrarian societies and children are expected to support their family throughout their life. Brazil is an economically developing ${ }^{1}$ and democratic South-American country characterized by stronger socioeconomic discrepancies compared to Germany. The inequality in the distribution of family income is much stronger in Brazil. For example, the GINI index ${ }^{2}$ for Brazil is 60.7 (rank 97) and 28.3 for Germany (rank 16) out of 100 countries (CIA, 2005b). Household income by percentage share is $0.7 \%$ for the lowest $10 \%$ in Brazil (3.6\% in Germany) and $48 \%$ of the highest $10 \%$ in Brazil $(25.1 \%$ in Germany; CIA, 2005c).

Furthermore, Brazil faces a strong modernization process. Highly industrialized areas can be found in urban areas, especially in the southern parts (e.g., Rio de Janeiro, Brasilia, and Sao Paulo). Collectivist cultures in transition to a modern society do not necessarily replace the collectivist by individualistic orientation but rather develop another pathway between autonomy and relatedness (see Kâgitçibâsi, 1996, 2005).

These different cultural norms (individualistic vs. collectivist) are reflected in the construal of the self at the individual level (Chao, 1995; Markus \& Kitayama, 1991, 1998) as well as in specific models of family that provide different developmental pathways (Greenfield, 1994; Greenfield, Keller, Fuligni, \& Maynard, 2003). Individuals in individualistic cultures emphasize the uniqueness, autonomy, and separateness of the self (independent selfconstrual) and this is even promoted within the family. Individuals in collectivist cultures emphasize group loyalty, dependence, and relatedness

\footnotetext{
'The GDP per capita in Brazil is $\$ 8,500$ (2005 est.) and $\$ 29,700$ (2005 est.) in Germany (CIA, 2005a).

${ }^{2}$ GINI index measures the degree of inequality in the distribution of family income in a country. The more nearly equal a country's income distribution, the lower its GINI index. The lowest documented value is 24.7 (Denmark) and the highest value is 63.2 (Lesotho).
} 
(interdependent self-construal) and families promote the interdependence (see also Rothbaum \& Trommsdorff, in press). Fostering independence would be a threat for such families. Families in societies in transition to modernity allow independence because the material contribution is not required so much but connectedness continues to be valued (Kâgitçibâsi, 1996, 2005). Therefore, individuals in such cultures emphasize independence as well as relatedness (interdependence).

German caregivers are expected to have a highly independent selfconstrual. The Brazilian caregivers of this study are expected to have a selfconstrual that is characterized by a mixture of both independent and interdependent aspects. The concern for independence may go hand in hand with a strong identification with the family and other social in-groups, resulting in a high degree of independence and interdependence at the same time.

The strong socioeconomic differences in Brazil are represented in the different working conditions of teachers in public kindergartens (with children of very low income families) and private kindergartens (with children of middle to high income families). For public kindergartens no fees are required; the teachers primarily serve children's basic needs, e.g., offering a warm lunch; space and play material are limited. Since the working conditions affect the construction of subjective beliefs (Goodnow \& Collins, 1990), these different realities within Brazil may lead to a great heterogeneity of caregivers' ethnotheories within the country. In Germany, the conditions for teachers in public and private kindergartens are rather similar to those of private kindergartens in Brazil. As we want to rule out the socioeconomic factor and related experiences as an explanation factor for the cross-cultural comparison, we selected a group of caregivers in Brazil with similar living and working conditions as the German group.

To summarize, we expect that German and Brazilian caregivers do not differ in independence but rather in interdependence of the self-construal, which will be higher for the Brazilians. Furthermore, we expect that German caregivers will show high preference for individual- and low preference for group-oriented goals. In contrast, Brazilian caregivers will stress both, individual- and group-oriented developmental goals, to the same extent. By this, German and Brazilian caregivers are expected to differ in their preference for both sets of developmental goals. We assume that this culture-related difference can be partly explained by taking caregivers' selfconstrual into account.

Achievement-oriented goals refer to the promotion of cognitive competence and academic success. It is argued that such goals are more heavily emphasized in individualistic than in collectivist cultures (e.g., Greenfield et al., 2003). However, achievement is also emphasized in collectivist countries in that the person's success is for the sake of the family and 


\section{FRIEDLMEIER ET AL.}

the group, rather than for the individual's pride (Yu \& Yang, 1994). Some studies have shown even higher emphasis in collectivist compared to individualistic cultural groups (see Schwartz, 1990). For example, mothers of preschool children in Hong Kong reported stronger emphasis on academic achievement than English mothers (Pearson \& Nirmala, 2003). Achievement may be especially emphasized in collectivist countries that face a transition to modern society. The modernization process includes social changes and such conditions suggest integration of collectivist group loyalties (primarily family based) with new individualistic achievements (Phalet \& Claeys, 1993). For example, Ispa (2002) reported that the relevance of academic related goals had strongly increased in Russia since the Perestroika for mothers and teachers mainly because the access to the public schools with high reputation was very competitive. In Brazil, individuals have a stronger concern for academic success in general (Furnham, Kirkcaldy, \& Lynn, 1996). Furthermore, it can be assumed that caregivers, especially mothers, may have a stronger concern that children get a good education. Due to this, a higher emphasis of achievement-oriented goals may occur in Brazil relative to Germany.

The expectation of culture-specific differences in the preference of achievement-oriented goals is also related to different cultural settings of the kindergarten in Brazil and Germany. As we study kindergarten teachers and mothers with 5-year-old children, achievement-oriented goals consist of: creativity, ability to concentrate on a task, being disciplined, and selfcontrol. While in Brazil learning the alphabet by children already takes place in kindergarten, in Germany the kindergartens emphasize play activities. German kindergarten teachers see their responsibility more in the child's preparation for school in terms of promoting the child's social competence and personality than in terms of promoting school-related skills like reading or writing (Tietze, 1998). These conditions may also contribute to a higher preference of achievement-oriented developmental goals of Brazilian as compared to German caregivers. No impact of self-construals on achievement-oriented goals is expected, since the emphasis of achievement is rather due to the cultural settings and development expectations and less the consequence of a specific self-perspective.

\section{Recognition/evaluation of cultural norms and preferences of developmental goals}

Up to now we have argued that the caregivers orient their goal preferences towards their personal beliefs and values based on their self-construal. However, there are alternative orientations that have to be taken into account (see Schäfermeier, 2004). The caregivers strive to foster the child's development of qualities and abilities needed to become a functioning 
member of society (LeVine, 1977; Rosenthal \& Roer-Strier, 2001). Caregivers may orient their developmental goals in line with perceived cultural expectations (normative cultural orientation), even if these are not in line with their personal beliefs and values. Members of a culture may recognize cultural norms and expectations in a similar way, but they may differ in their degree of personal agreement with these norms (evaluative cultural orientation) (see Bierbrauer, Meyer, \& Wolfradt, 1994). This implies that members of a culture differ in their degree of internalization of such norms (Spiro, Kilborne, \& Langness, 1994). Therefore, it is necessary to differentiate between the recognition of cultural norms (collectivist vs. individualistic), i.e., practices that are recognized as common in a specific culture, and the evaluation of these norms in regard to their desirability, i.e., sharing these collectivist vs. individualistic practices (Bierbrauer et al., 1994). The question, therefore, is whether the caregivers will orient their preferences of developmental goals rather in accordance with the perceived cultural norms (normative cultural orientation) or with their personal beliefs (evaluative cultural orientation). Here, non-conform caregivers, i.e., caregivers who show a strong discrepancy between the recognition and the evaluation of cultural norms, are of specific interest to answer this question empirically.

\section{Individual differences on preferences of developmental goals}

In most studies about developmental goals only mothers were interviewed (New \& Richman, 1996). It is tacitly assumed that teachers and mothers may agree strongly or complement each other in the preschool period. However, a study with Japanese kindergarten teachers showed that most of the teachers claimed that mothers should emphasize more goals related to social behaviour by providing firm guidance and not so much emphasis on academic training (Holloway, 2000). As professional caregivers were rather neglected in previous research (e.g., Rosenthal \& Roer-Strier, 2001), there is little information available about their goal preferences. Different childrearing beliefs can be expected due to the different information background. Mothers who normally do not undergo a formal training for parenting construct their developmental goals based on their own socialization, e.g., their experiences during their own child-rearing process, or through the media. This means that they may emphasize former traditional beliefs or may follow newly promoted cultural child-rearing beliefs. In contrast, professional caregivers like kindergarten teachers learn about child-rearing theories through their professional training based on educational curricula that reflect the current cultural emphasis of relevant goals and strategies provided by educational laws and institutions. For example, recent educational legislation on children's education (e.g., the national curriculum 
for young children's education in 1998, see Brazil, 1998, 1999) focus on the promotion of autonomy. Since Brazilian teachers are requested to put these laws into practice, the expected balance between individual- and grouporiented developmental goals for teachers in Brazil may be stronger whereas mothers may still show higher preference for group-oriented goals. Therefore, Brazilian teachers may pursue developmental goals more related to the current culture-specific expectations.

\section{Summary of hypotheses and research questions}

This study focuses on four main research hypotheses. German caregivers' are more individualistic, and less interdependent than Brazilian caregivers (Hypothesis 1). German caregivers prefer individual-oriented developmental goals (e.g., independence and autonomy) more and group-oriented (e.g., co-operation) as well as achievement-oriented goals (e.g., ability to concentrate) less than Brazilian caregivers (Hypothesis 2). It is expected that caregivers with stronger interdependent self-construal show higher preference for group-oriented goals whereas caregivers with stronger independent self-construal show higher preference of individual-oriented child-rearing goals (Hypothesis 3). It is further assumed that those caregivers with rather individualistic cultural norms prefer individualoriented developmental goals, while those caregivers with rather collectivist norms prefer group-oriented goals (Hypothesis 4).

It is an important research question here whether the perceived cultural norms are related to the developmental goal preferences. Furthermore, we will test differences between professional and nonprofessional caregivers regarding goal preferences, regarding the relations between personal beliefs (self-construal and evaluative cultural orientation) and goal preferences as well as regarding the relations between perceived norms and developmental goal preferences.

\section{METHOD}

\section{Participants}

A total of 78 caregivers ( $n=38$ kindergarten teachers and $n=40$ mothers) living in the area of Konstanz, Germany, and 50 caregivers $(n=25$ kindergarten teachers and $n=25$ mothers) living in the area of Niteroi, Rio de Janeiro, Brazil, participated in the study. All Brazilian mothers, who participated in this study, had their children in a private kindergarten, while the children of the German mothers attended public kindergartens. The mean age of the children was 5.4 years in both groups. Both groups represent middle-class families. 
The German and the Brazilian kindergarten teachers did not differ significantly in age $\left(M_{\mathrm{G}}=31.02, S D_{\mathrm{G}}=7.53, M_{\mathrm{Br}}=30.11, S D_{\mathrm{Br}}=4.65\right.$, $t(69.9)=0.63, n s)$, education $(23.26 \%$ of the German and $25.93 \%$ of the Brazilian teachers had university training, $\left.\chi^{2}(1)=0.06, n s\right)$, daily working time $(73.33 \%$ of the German and $61.54 \%$ of the Brazilian teachers worked full time, $\chi^{2}(1)=1.07$, ns. $)$, or parenthood $(28.89 \%$ of the German and $44.44 \%$ of the Brazilian teachers had own children, $\chi^{2}(1)=1.80$, ns). The Brazilian teachers had worked in their profession for about the same period of time as the Germans $\left(M_{\mathrm{G}}=7.62\right.$ years, $S D_{\mathrm{G}}=5.92, M_{\mathrm{Br}}=9.96$ years, $\left.S D_{\mathrm{Br}}=6.02, t(70)=1.61, n s\right)$. The German and Brazilian families of the mothers did not differ in the size of the household members $\left(M_{\mathrm{G}}=3.85\right.$, $\left.S D_{\mathrm{G}}=0.96, \quad M_{\mathrm{Br}}=3.73, S D_{\mathrm{Br}}=0.83, t(71)=0.54, n s\right)$. No significant difference was found for education $(36.17 \%$ of the German and $23.08 \%$ of the Brazilian mothers had university education, $\chi^{2}(1)=1.33, n s$ ). Both groups differed in their current professional status. Only $55.32 \%$ of the German compared to $96.15 \%$ of the Brazilian mothers were practicing an occupation, $\chi^{2}(1)=18.43, p<.01$. Most of these German working mothers worked half-time $(80.77 \%)$ whereas nearly $50 \%$ of the Brazilian working mothers worked full time. All fathers in Germany and in Brazil were practicing an occupation at the time of the interviews and most of them worked full time $(82.61 \%$ for German and $79.17 \%$ for Brazilian fathers, $\left.\chi^{2}(1)=0.12, n s\right)$.

\section{Procedure}

The kindergarten teachers were contacted and interviewed in a room of their respective kindergartens. The interviews lasted for about one hour and were done individually. The interview covered several aspects of child-rearing theories. In the beginning, they were asked about their developmental goals as an open question. Then twelve given goals were presented on single cards. The teachers were asked to choose and rank the five most important goals. Further topics of the interview (e.g., educational strategies and their effectiveness, characteristics of an ideal child) are not included in this analysis. The questionnaires measuring the self-construal and the cultural orientation were answered after the interview. The same procedure was used for mothers, who were interviewed at home.

\section{Instruments and measures}

Developmental goals. Based on the reviewed studies and on a pilot study with Brazilian and German teachers (Friedlmeier, 1995; Vasconcellos \& Friedlmeier, 1994), 12 developmental goals were selected and categorized into three main sets of developmental goals: individual-oriented 
(autonomy, independence, self-realization, and tolerance), group-oriented (e.g., sensitivity for others' needs, co-operation, responsibility for others, and ability to interact), and achievement-oriented goals (the ability to concentrate, creativity, discipline, and initiative). The final terms were checked for equivalent translations into German and Portuguese during a meeting between the Brazilian and the German teams.

In order to empirically validate this categorization, the caregivers were asked to give a written description of the subjective meaning of these 12 goals. Qualitative analyses confirmed the validity of the categorization of the goals into the 3 groups. For example, a comparison between definitions for Brazilian and German caregivers with regard to the goal "autonomy" showed that not the meaning but the importance differed between the two cultural groups (Friedlmeier \& Schäfermeier, 2001).

The 12 goals represent heterogeneous items. Heterogeneous items share similar meanings but they do not necessarily cluster together in a quantitative perspective: The selection of an individual-oriented goal like autonomy does not necessarily imply a higher probability for the selection of another individual-oriented goal like independence (see Sixtl, 1967). ${ }^{3}$ Therefore, no internal consistency is expected. To determine the preferences of the developmental goals with regard to the three groups of goals, the rankings of each of these sets $(5$ - most important; 4 - second most important; 3 -third most important; 2 -fourth most important; 1 - fifth most important; 0 - not selected) were computed. Since each set was represented by four goals, a person could choose a maximum of all four goals from the same group. The maximum value for one set was 14 points.

Self-construal. The Self-Construal Scales (SCS) from Singelis (1994) consist of 30 items with 7-point scales. The items describe thoughts, feelings, and actions that are characteristic of either an independent (e.g., I enjoy being unique and different from others in many respects) or an interdependent self-construal (e.g., It is important for me to maintain harmony within my group). One additional item was used in this study that asked directly for independence: It is very important for me to see me as independent from others. Therefore, the scale for the independent selfconstrual consisted of 16 items, the scale for the interdependent self-construal of 15 items. This instrument was translated and back translated from English

\footnotetext{
${ }^{3}$ Heterogeneous items are rarely used. Therefore, an example may provide better comprehension. By studying hobbies, we may present a list of hobbies and ask the subjects to select up to five hobbies and to rank them. The list may contain tennis, soccer, weight lifting, movies, reading, theatre, and so on. The fact that someone chooses "tennis" does not increase the probability for choosing another sport like "soccer" or "weight lifting". Nevertheless, we can summarize for each person their rankings by differentiating general sets of hobbies like preference for "sport" or "cultural events".
} 
into Portuguese as well as from English into German. Previous studies reported moderately high internal consistencies $(\alpha=.69$ for independent and $\alpha=.73$ for interdependent self-construal; Singelis \& Brown, 1995). Construct and predictive validity of the instrument was reported by Singelis (1994).

The internal consistency of the two scales of the current study was moderately high and no cultural differences occurred (independent selfconstrual: $\alpha_{\mathrm{G}}=.69 ; \alpha_{\mathrm{Br}}=.71$; interdependent self-construal: $\alpha_{\mathrm{G}}=.64$; $\alpha_{\mathrm{Br}}=.70$ ). The alpha values did not differ between the two groups: independent self-construal, $F(77,49)=1.07$, $n s$; interdependent self-construal, $F(77,49)=1.20, n s$.

Cultural orientation. The Cultural Orientation Scale (COS) from Bierbrauer et al. (1994) differentiates between perceived collectivist (a person's identity is integrated into in-groups) and individualistic norms (a person's identity is independent of others) and their individual evaluation. Bierbrauer et al. (1994) tested two collectivist measures (Hui, 1988; Sinha \& Verma, 1987) in a sample with Germans and a group of immigrants from Turkey and Iran. They selected the items with the highest inter item correlations $\left(r_{\mathrm{it}}>40\right)$. The items describe behaviour standards and ask for the frequency of such behaviour (e.g., How often does someone care for a sick family member instead of going to work?; How often do children live with their parents until they marry?; How often do adolescents refer to suggestions of parents or close relatives for decision about their profession?). All items are answered by 7-point scales from $1=$ never to $7=$ always. For individual evaluation the same items are presented by asking whether such behaviour is desirable or not (e.g., How do you evaluate the fact that someone cares for a sick family member instead of going to work?; How do you evaluate the fact that children live with their parents until they marry; How do you evaluate the fact that adolescents choose their profession by suggestions of parents or close relatives?) The answer options range from $1=$ very bad to $7=$ very good. This instrument was originally in German. It was translated and back translated from German to Portuguese.

The internal consistencies reported in other studies varied between .56 and .82 (e.g., Cialdini, Wosinska, Barrett, Butner \& Gornik-Durose, 1999; Goodwin \& Plaza, 2000). Construct validity (Bierbrauer et al., 1994; Goodwin \& Plaza, 2000) and predictive validity (Cialdini et al., 1999) were reported.

In the current study, the internal consistencies based on all items were low in both cultural groups. It was necessary to eliminate 8 items (parallel in both scales) in order to get a consistent set for both cultural groups and both scales, and to reach moderately high internal consistencies (normative cultural orientation: $\alpha_{\mathrm{G}}=.60 ; \alpha_{\mathrm{Br}}=.65$; evaluative cultural orientation: 
$\left.\alpha_{G}=.65 ; \alpha_{B r}=.48\right)$. The alphas did not differ between the two groups; $F(77,49)=1.14, n s$, for normative cultural orientation and $F(49,77)=1.49$, $n s$, for evaluative cultural orientation.

Two variables were constructed: "normative cultural orientation"- the higher the score the more collectivist the person perceives the society - and "evaluative cultural orientation"- the higher the score the more collectivist is the person's own cultural orientation.

Finally, to identify non-conform caregivers, a discrepancy index was computed by subtracting the value of the evaluative from the value of the normative cultural orientation. A positive value indicates that the person is more collectivist opposed to a perceived more individualistic culture; a negative value indicates that the person is more individualistic opposed to a perceived more collectivist culture. As we are interested in non-conform caregivers, the amount but not the direction of the subtraction was relevant. Therefore, absolute values were further analysed. The range of discrepancy values was between 0 and 3.4. The upper third of the distribution of the discrepancy index was used to create "non-conform caregivers" as a subsample for each cultural group.

\section{RESULTS}

\section{Self-construal and cultural orientation (Hypothesis 1)}

A series of 2 (Culture) $\times 2$ (Caregiver) ANOVAs were computed to analyse differences in the self-construal. As expected, Brazilian $(M=4.71, S D=0.63)$ compared to German caregivers $(M=4.13, S D=0.50)$ had a significantly higher interdependent self-construal (see Table 1). Neither of the groups differed in the extent of their independent self-construal, $F(1,127)<1.0$, ns (see Table 1).

The same 2-way ANOVAs were computed for cultural orientation. The main effect "Culture" was significant for normative cultural orientation. The Brazilian $(M=4.19, S D=0.83)$ compared to the German caregivers $(M=3.94, S D=0.58)$ perceived their society as more collectivist (see Table 1). For evaluative cultural orientation, the interaction effect was significant. German caregivers (mothers: $M=4.99, S D=0.65$; teachers: $M=4.90, S D=0.68)$ and Brazilian mothers $(M=5.10, S D=0.52)$ did not differ in their evaluative orientation. However, Brazilian teachers $(M=5.54$, $S D=0.72$ ) showed a more collectivist norm orientation compared to the three other groups (see Table 1).

A comparison of the normative and evaluative orientation means within each group showed a consistent pattern: the majority of caregivers personally had a more collectivist orientation than they perceived to prevail in their society in general (see Table 1). 
TABLE 1

Cultural comparison of self-construal and cultural orientation

\begin{tabular}{|c|c|c|c|c|c|c|c|}
\hline & \multicolumn{2}{|c|}{ Germany } & \multicolumn{2}{|c|}{ Brazil } & \multirow[b]{2}{*}{ F-value } & \multirow[b]{2}{*}{$R^{2}(\%)$} & \multirow{2}{*}{$\begin{array}{l}\text { F-value for } \\
\text { single effects } \\
\text { A: Culture } \\
\text { B: Caregiver } \\
\text { C: Interaction }\end{array}$} \\
\hline & $\begin{array}{c}\text { Mother }(n=40) \\
M \\
(S D)\end{array}$ & $\begin{array}{c}\text { Teacher }(n=38) \\
M \\
(S D)\end{array}$ & $\begin{array}{c}\text { Mother }(n=25) \\
M \\
(S D)\end{array}$ & $\begin{array}{c}\text { Teacher }(n=25) \\
M \\
(S D)\end{array}$ & & & \\
\hline \multicolumn{8}{|l|}{ Self-construal } \\
\hline Independent' & $\begin{array}{c}4.88 \\
(0.61)\end{array}$ & $\begin{array}{l}4.83 \\
(0.46)\end{array}$ & $\begin{array}{c}4.87 \\
(0.58)\end{array}$ & $\begin{array}{c}4.90 \\
(0.64)\end{array}$ & 0.06 & 0.09 & $\begin{array}{l}\text { A: } 0.06 \\
\text { B: } 0.05\end{array}$ \\
\hline Interdependent ${ }^{1}$ & $\begin{array}{l}4.15 \\
(0.58)\end{array}$ & $\begin{array}{l}4.11 \\
(0.42)\end{array}$ & $\begin{array}{c}4.81 \\
(0.49)\end{array}$ & $\begin{array}{l}4.60 \\
(0.73)\end{array}$ & $16.95^{* * *}$ & 21.34 & $\begin{array}{l}\text { A: } 32.95^{* * *} \\
\text { B: } 1.11\end{array}$ \\
\hline \multicolumn{8}{|l|}{ Cultural orientation } \\
\hline Normative ${ }^{\prime}$ & $\begin{array}{c}3.84 \\
(0.55)\end{array}$ & $\begin{array}{l}4.05 \\
(0.61)\end{array}$ & $\begin{array}{c}4.10 \\
(0.67)\end{array}$ & $\begin{array}{c}4.29 \\
(0.98)\end{array}$ & $3.48^{*}$ & 5.28 & $\begin{array}{l}\text { A: } 3.97^{*} \\
\text { B: } 2.91^{+}\end{array}$ \\
\hline Evaluative' & $\begin{array}{r}4.99^{a} \\
(0.65)\end{array}$ & $\begin{array}{r}4.90^{\mathrm{a}} \\
(0.68)\end{array}$ & $\begin{array}{l}5.10^{\mathrm{a}} \\
(0.52)\end{array}$ & $\begin{array}{r}5.54^{b} \\
(0.72)\end{array}$ & $5.41^{* *}$ & 11.57 & $\begin{array}{l}\text { A: } 10.37^{* *} \\
\text { B: } 2.19 \\
\text { C: } 4.86^{*}\end{array}$ \\
\hline
\end{tabular}

Notes: 'Range of values from 1 to $7 .{ }^{2}$ When the interaction term was not significant, the main effect model was analysed in a second run. ${ }^{+} p<.10 ; * p<.05 ; * * p<.01 ; * * *<.001$ 


\section{Cultural comparison of developmental goals (Hypothesis 2)}

A series of 2 (Culture) $\times 2$ (Caregiver) ANOVAS were computed to test differences of developmental goals. Since the goals represent heterogeneous items, the single goals were also analysed in order to test which goal contributes to the results of the group of goals. No significant interaction effect occurred except for two specific goals: autonomy and ability to interact.

As expected, German $(M=7.06, S D=2.86)$ compared to Brazilian caregivers $(M=4.31, S D=2.75)$ preferred significantly more individualoriented developmental goals (see Table 2). These differences were primarily based on the preference of the goals "autonomy" and "tolerance". There were no differences for "self-realization" and "independence" yielded a higher mean for Brazilian compared to German caregivers. The cultural groups did not differ in their preference for group-oriented developmental goals overall nor in one of the single goals (see Table 2). Brazilian caregivers $(M=5.67, S D=2.76)$ preferred achievement-oriented developmental goals more than the German caregivers $(M=5.14, S D=2.51)$ (see Table 2). Significant differences occurred for the goals "initiative" and "discipline", while there were no differences for "creativity" and "ability to concentrate".

No significant main effect of caregiver was found for the three groups of developmental goals (see Table 2). However, some significant caregiver effects appeared by analysing single goals: German and Brazilian mothers ranked the goals "responsibility" and "discipline" significantly higher compared to the teachers. Two intra-cultural differences occurred for the Brazilian sample: Brazilian teachers ranked the goal "ability to interact" higher than the mothers and the German caregivers. Brazilian mothers ranked the goal "autonomy" lower as compared to the teachers who showed lower preference compared to German caregivers (see Table 2).

\section{Effects of self-construal and cultural orientations on the preference of developmental goals}

Hierarchical regression analyses were performed to test whether selfconstrual and the cultural orientation scales predict differences in preferred developmental goals, and to test whether these relations vary across cultural groups and status of caregivers. The correlation matrix of all predictors and predicted variables is presented in Table 3 . The regression analyses were carried out in four steps. Culture and status of caregiver (as dummy variables) were entered first. Independence, interdependence, normative and evaluative cultural orientation were added as predictors in a second step. Two-way interaction terms of culture with each of the four predictor variables were entered in the third step (step 3a) in order to test whether 
TABLE 2

Cultural comparison of developmental goals

\begin{tabular}{|c|c|c|c|c|c|c|c|}
\hline \multirow[b]{2}{*}{ Developmental goals } & \multicolumn{2}{|c|}{ Germany } & \multicolumn{2}{|c|}{ Brazil } & \multirow[b]{2}{*}{ F-value } & \multirow[b]{2}{*}{$R^{2}(\%)$} & \multirow{2}{*}{$\begin{array}{l}\text { F-value for } \\
\text { single effects } \\
\text { A: Culture } \\
B: \text { Caregiver } \\
C: A \times B^{\prime}\end{array}$} \\
\hline & $\begin{array}{c}\text { Mother }(n=40) \\
M \\
(S D)\end{array}$ & $\begin{array}{c}\text { Teacher }(n=38) \\
M \\
(S D)\end{array}$ & $\begin{array}{c}\text { Mother }(n=25) \\
M \\
(S D)\end{array}$ & $\begin{array}{c}\text { Teacher }(n=25) \\
M \\
(S D)\end{array}$ & & & \\
\hline Individual-oriented & $\begin{array}{c}6.90 \\
(3.19)\end{array}$ & $\begin{array}{c}7.24 \\
(2.50)\end{array}$ & $\begin{array}{c}4.36 \\
(2.87)\end{array}$ & $\begin{array}{c}4.36 \\
(2.80)\end{array}$ & $9.17^{* * *}$ & 18.16 & $\begin{array}{l}\text { A: } 27.33^{* * * *} \\
\text { B: } 0.11\end{array}$ \\
\hline Autonomy & $\begin{array}{r}3.25^{\mathrm{c}} \\
(1.93)\end{array}$ & $\begin{array}{r}3.34^{c} \\
(1.83)\end{array}$ & $\begin{array}{r}0.84^{a} \\
(1.60)\end{array}$ & $\begin{array}{r}2.12^{\mathrm{b}} \\
(1.94)\end{array}$ & $11.85^{* * *}$ & 22.28 & $\begin{array}{l}\text { A: } 29.52^{* * *} \\
\text { B: } 4.21^{*} \\
\text { C: } 3.16^{+}\end{array}$ \\
\hline Independence & $\begin{array}{c}0.50 \\
(1.34)\end{array}$ & $\begin{array}{c}0.34 \\
(1.07)\end{array}$ & $\begin{array}{c}1.76 \\
(1.83)\end{array}$ & $\begin{array}{c}1.20 \\
(1.87)\end{array}$ & $5.73^{* *}$ & 12.18 & $\begin{array}{l}\text { A: } 15.28^{* * *} \\
\text { B: } 1.76\end{array}$ \\
\hline Tolerance & $\begin{array}{c}2.13 \\
(1.68)\end{array}$ & $\begin{array}{c}1.82 \\
(1.86)\end{array}$ & $\begin{array}{c}0.44 \\
(1.16)\end{array}$ & $\begin{array}{c}0.32 \\
(0.90)\end{array}$ & $11.34^{* * * *}$ & 21.53 & $\begin{array}{l}\text { A: } 32.98^{* * * *} \\
\text { B: } 0.60\end{array}$ \\
\hline Self-realization & $\begin{array}{c}1.20 \\
(1.91)\end{array}$ & $\begin{array}{c}1.97 \\
(2.07)\end{array}$ & $\begin{array}{l}1.68 \\
(2.14)\end{array}$ & $\begin{array}{c}1.16 \\
(1.55)\end{array}$ & 1.39 & 3.26 & $\begin{array}{ll}\text { A: } & 0.22 \\
\text { B: } & 0.13\end{array}$ \\
\hline Group-oriented & $\begin{array}{c}5.05 \\
(2.67)\end{array}$ & $\begin{array}{c}5.24 \\
(2.35)\end{array}$ & $\begin{array}{c}5.04 \\
(1.99)\end{array}$ & $\begin{array}{c}6.16 \\
(3.31)\end{array}$ & 1.12 & 2.64 & $\begin{array}{ll}\text { A: } & 0.94 \\
\text { B: } & 1.92\end{array}$ \\
\hline Responsibility & $\begin{array}{c}2.63 \\
(1.58)\end{array}$ & $\begin{array}{c}2.11 \\
(1.78)\end{array}$ & $\begin{array}{c}3.08 \\
(1.58)\end{array}$ & $\begin{array}{c}2.36 \\
(1.98)\end{array}$ & 1.73 & 4.02 & $\begin{array}{ll}\text { A: } & 1.29 \\
\text { B: } & 3.94^{*}\end{array}$ \\
\hline Ability to interact & $\begin{array}{l}1.05^{\mathrm{ab}} \\
(1.54)\end{array}$ & $\begin{array}{r}0.89^{a} \\
(1.29)\end{array}$ & $\begin{array}{r}0.40^{a} \\
(1.04)\end{array}$ & $\begin{array}{r}1.72^{\mathrm{b}} \\
(2.09)\end{array}$ & $3.26^{*}$ & 7.32 & $\begin{array}{ll}\text { A: } & 0.10 \\
\text { B: } & 4.50^{*} \\
\text { C: } & 7.22^{* *}\end{array}$ \\
\hline Sensibility & $\begin{array}{c}1.18 \\
(1.65)\end{array}$ & $\begin{array}{c}1.79 \\
(1.95)\end{array}$ & $\begin{array}{c}1.16 \\
(1.52)\end{array}$ & $\begin{array}{c}1.16 \\
(1.89)\end{array}$ & 1.11 & 2.61 & $\begin{array}{ll}\text { A: } & 1.01 \\
\text { B: } & 0.92\end{array}$ \\
\hline Co-operation & $\begin{array}{c}0.60 \\
(1.34)\end{array}$ & $\begin{array}{c}0.89 \\
(1.43)\end{array}$ & $\begin{array}{c}0.72 \\
(1.17)\end{array}$ & $\begin{array}{c}1.12 \\
(1.64)\end{array}$ & 0.79 & 1.88 & $\begin{array}{ll}\text { A: } & 0.46 \\
\text { B: } & 1.88\end{array}$ \\
\hline
\end{tabular}


TABLE 2

(Continued)

\begin{tabular}{|c|c|c|c|c|c|c|c|}
\hline \multirow[b]{2}{*}{ Developmental goals } & \multicolumn{2}{|c|}{ Germany } & \multicolumn{2}{|c|}{ Brazil } & \multirow[b]{2}{*}{ F-value } & \multirow[b]{2}{*}{$R^{2}(\%)$} & \multirow{2}{*}{$\begin{array}{l}\text { F-value for } \\
\text { single effects } \\
\text { A: Culture } \\
B \text { : Caregiver } \\
C: A \times B^{\prime}\end{array}$} \\
\hline & $\begin{array}{c}\text { Mother }(n=40) \\
M \\
(S D)\end{array}$ & $\begin{array}{c}\text { Teacher }(n=38) \\
M \\
(S D)\end{array}$ & $\begin{array}{c}\text { Mother }(n=25) \\
M \\
(S D)\end{array}$ & $\begin{array}{c}\text { Teacher }(n=25) \\
M \\
(S D)\end{array}$ & & & \\
\hline Achievement-oriented & $\begin{array}{c}1.93 \\
(2.03)\end{array}$ & $\begin{array}{c}1.53 \\
(1.54)\end{array}$ & $\begin{array}{c}4.20 \\
(3.29)\end{array}$ & $\begin{array}{c}3.48 \\
(2.68)\end{array}$ & $8.82^{* * *}$ & 17.59 & $\begin{array}{l}\text { A: } 24.81^{* * *} \\
\text { B: } 1.74\end{array}$ \\
\hline Creativity & $\begin{array}{c}1.38 \\
(1.58)\end{array}$ & $\begin{array}{c}1.50 \\
(1.41)\end{array}$ & $\begin{array}{c}1.52 \\
(1.76)\end{array}$ & $\begin{array}{c}1.72 \\
(1.70)\end{array}$ & 0.24 & 0.58 & $\begin{array}{ll}\text { A: } & 0.40 \\
\text { B: } & 0.32\end{array}$ \\
\hline Ability to concentrate & $\begin{array}{c}0.25 \\
(0.63)\end{array}$ & $\begin{array}{c}0.16 \\
(0.49)\end{array}$ & $\begin{array}{c}0.68 \\
(1.38)\end{array}$ & $\begin{array}{c}0.64 \\
(1.35)\end{array}$ & $2.36^{+}$ & 5.40 & $\begin{array}{l}\text { A: } 6.91^{* *} \\
\text { B: } 0.14\end{array}$ \\
\hline Initiative & $\begin{array}{c}0.30 \\
(1.04)\end{array}$ & $\begin{array}{c}0.16 \\
(0.67)\end{array}$ & $\begin{array}{c}0.92 \\
(1.71)\end{array}$ & $\begin{array}{c}0.64 \\
(1.25)\end{array}$ & $2.61^{+}$ & 5.95 & $\begin{array}{l}\text { A: } 6.87^{* *} \\
\text { B: } 1.01\end{array}$ \\
\hline Discipline & $\begin{array}{c}0.40 \\
(1.13)\end{array}$ & $\begin{array}{c}0.03 \\
(0.16)\end{array}$ & $\begin{array}{c}1.40 \\
(1.98)\end{array}$ & $\begin{array}{c}0.80 \\
(1.44)\end{array}$ & $6.57^{* * *}$ & 13.71 & $\begin{array}{l}\text { A: } 15.27^{* * *} \\
\text { B: } 4.60^{*}\end{array}$ \\
\hline
\end{tabular}

Note: 'When the interaction term was not significant, the main effect model was analysed in a second run. ${ }^{a, b . c}$ Means with same letter do not differ significantly.

$+p<.10 ; *^{*} p<.05 \quad .01 ;{ }^{* * *} p<.001$. 
TABLE 3

Correlation matrix for all variables (total sample: $n=128$ )

\begin{tabular}{lrrrrrrr}
\hline & 1 & 2 & 3 & 4 & 5 & 6 & 7 \\
\hline Predictor variables & & & & & & & \\
1 Independence & -.14 & - & & & & & \\
2 Interdependence & -.01 & .11 & - & & & & \\
3 Normative orientation & .09 & $.39^{* * *}$ & $.35^{* * *}$ & - & & & \\
4 Evaluative orientation & & & & & & & \\
Predicted variables & -.02 & -.14 & $-.26^{* *}$ & -.14 & - & & \\
5 Individual-oriented goals & -.08 & .09 & $.31^{* * *}$ & .06 & $-.60^{* * *}$ & - & \\
6 Group-oriented goals & .08 & .04 & .01 & .10 & $-.59^{* * *}$ & $-.26^{* *}$ & - \\
7 Achievement-oriented goals & 4.87 & 4.36 & 4.04 & 5.09 & 6.02 & 5.34 & 2.52 \\
Means & 0.56 & 0.62 & 0.70 & 0.68 & 3.11 & 2.62 & 2.57 \\
SD & & & & & & &
\end{tabular}

Note: ${ }^{* *} p<.01 ; * * * p<.001$.

the regression lines differ between the two cultural groups; the same test was run for interaction terms of caregivers (step 3b). The continuous predictors were centred before the multiplication with the dummy variables was carried out (see Aiken \& West, 1991). Table 4 summarizes changes from step to step. Simple slope test were used to test significant interaction effects.

Individual-oriented developmental goals (Hypotheses 3 and 4). The regression analysis on individual-oriented goals at step 2 explained $22 \%$ of the variance with an increase of $4 \%$ (see Table 4 ). Normative cultural orientation resulted as the significant predictor, $\beta=-.21, p<.05$ : The more caregivers perceived the culture as characterized by collectivist norms the less they preferred individual-oriented goals. Both, the interaction terms of culture (step 3a) and of caregivers (step 3b) increased the explained variance to $27 \%$ (see Table 4 ). The interaction "culture $\times$ normative orientation", $\beta=.23, p<.05$, as well as "culture $\times$ evaluative orientation" had a significant effect on individual-oriented goals, $\beta=-.30, p<.05$. Simple slope tests for normative orientation showed a significant slope for German caregivers, $\beta=-.31, t=2.57, p<.05$, but not for Brazilian caregivers, $\beta=-.09, t<0.88$, ns. For evaluative orientation the slopes for Brazil, $\beta=-.09$, and Germany, $\beta=.02$, pointed in different directions but none of them were significant. The interaction between caregiver and normative orientation was marginally significant, $\beta=.20, p<.10$. Simple slope tests showed predictive power for mothers, $\beta=-.46, t=3.28, p<.01$, but not for teachers, $\beta=-.15, t=1.35$, ns. 
TABLE 4

Hierarchical regressions of self-construal and cultural orientations on preference of developmental goals

\begin{tabular}{|c|c|c|c|c|c|c|c|c|c|}
\hline & \multicolumn{3}{|c|}{ Individual-oriented goals } & \multicolumn{3}{|c|}{ Group-oriented goals } & \multicolumn{3}{|c|}{ Achievement-oriented goals } \\
\hline & $R^{2}$ & $\Delta R^{2}$ & $\beta$ & $R^{2}$ & $\Delta R^{2}$ & $\beta$ & $R^{2}$ & $\Delta R^{2}$ & $\beta$ \\
\hline Step 1 & .19 & .19 & & .02 & .02 & & .17 & .17 & \\
\hline Culture $^{u}$ & & & $.43^{* * *}$ & & & -.14 & & & $-.38 * * *$ \\
\hline Status of Caregiver ${ }^{b}$ & & & -.05 & & & -.08 & & & .09 \\
\hline Step 2 & .22 & $.04^{*}$ & & .11 & $.09 * *$ & & .21 & $.04 *$ & \\
\hline Independence & & & -.01 & & & -.06 & & & .04 \\
\hline Interdependence & & & .07 & & & .08 & & & $-.21^{*}$ \\
\hline Normative orientation & & & $-.21^{*}$ & & & $.32^{* * *}$ & & & .06 \\
\hline Evaluative orientation & & & .02 & & & -.10 & & & .07 \\
\hline Step 3a & .27 & $.05^{*}$ & & .15 & $.04^{*}$ & & .24 & $.03^{+}$ & \\
\hline Culture $\times$ Independence & & & .13 & & & -.18 & & & .03 \\
\hline Culture $\times$ Interdependence & & & $.22^{+}$ & & & .04 & & & $-.24^{+}$ \\
\hline Culture $\times$ Normative orientation & & & $.23^{*}$ & & & -.15 & & & -.15 \\
\hline Culture $\times$ Evaluative orientation & & & $-.30^{*}$ & & & $.31^{+}$ & & & .12 \\
\hline Step 3b & .27 & $.05^{*}$ & & .22 & $.11^{* *}$ & & .27 & $.06^{*}$ & \\
\hline Caregiver $\times$ Independence & & & .15 & & & $-.28^{*}$ & & & .14 \\
\hline Caregiver $\times$ Interdependence & & & -.17 & & & .23 & & & .03 \\
\hline Caregiver $\times$ Normative orientation & & & $.20^{+}$ & & & .05 & & & $-.30^{* *}$ \\
\hline Caregiver $\times$ Evaluative orientation & & & -.08 & & & .10 & & & .00 \\
\hline
\end{tabular}

Note: ${ }^{\mathrm{a}} 0=$ Brazil, $1=$ Germany; ${ }^{b} 0=$ teachers, $1=$ mothers; ${ }^{+} p<.10 ;{ }^{*} p<.05 ;{ }^{* *} p<.01 ;{ }^{* * *} p<.001$. 
These results of step 3 qualify the result of step 2 in the following way: A decreasing preference of individual-oriented goals due to perceived collectivist norms is only valid for the German but not for the Brazilian caregivers and at the same time only for mothers but not for teachers. Therefore, Hypotheses 3 and 4 were not confirmed for individual-oriented developmental goals.

Group-oriented developmental goals (Hypotheses 3 and 4). The regression analysis at step 2 explained $11 \%$ of the variance of group-oriented goals with an increase of $9 \%$. The result pattern was reversed compared to individual-oriented goals. Normative cultural orientation had a significant positive effect, $\beta=.32, p<.001$ (see Table 4): The more the caregivers perceived their culture as characterized by collectivist norms the more they preferred group-oriented goals.

The interaction terms with culture (step 3a) yielded a marginally significant predictor for evaluative orientation, $\beta=-.31, p<.10$. Similar to the results for individual-oriented goals, the slopes for Brazil and Germany pointed in different directions $(\beta=.23, t=1.56, n s ; \beta=-.09$, $t=0.77, n s$, respectively) but none of them were significant. The interaction terms with caregiver (step $3 \mathrm{~b}$ ) increased the explained variance to $22 \%$ with an increase of $11 \%$. Independence was a significant predictor, $\beta=-.28$, $p<.05$. Simple slope analysis showed predictive power for teachers, $\beta=-.32, t=2.45, p<.05$, but not for mothers, $\beta=.11, t=0.94, n s$. This means that mothers' goal preferences are primarily oriented to the perceived cultural norms: The more collectivist the perception of cultural norms, the stronger is their preference for group-oriented goals. Beside perceived cultural norms, independence self-construal was predictive for teachers: The lower their independent self-construal, the higher was their preference for group-oriented developmental goals. Therefore, Hypothesis 3 was only confirmed for teachers' group-oriented goals. Hypothesis 4 was not confirmed.

Achievement-oriented developmental goals. The regression on achievement-oriented goals explained $21 \%$ of the variance with an increase of $4 \%$ at step 2 . The interdependent self-construal had a significant negative effect, $\beta=-.21, p<.001$ (see Table 4 ). The higher the caregivers' interdependent self-construal the less they preferred achievement-oriented goals.

The interaction terms with caregivers (step $3 \mathrm{~b}$ ) showed an increase of $6 \%$ explained variance. The interaction with normative orientation was significant, $\beta=-.30, p<.01$. Simple slope analyses yielded predictive power for mothers, $\beta=.35, t=2.50, p<.05$, the slope for teachers even pointed in a negative direction, $\beta=-.18, t=1.58$, ns. The more that 
mothers perceived cultural norms as collectivist, the higher was their preference for achievement-oriented goals. In contrast, teachers' perception of collectivist norms rather decreased their preference for achievementoriented goals.

\section{Effects of cultural orientations on the preference of developmental goals for non-conform caregivers}

We were also interested in testing the effect of personal values (evaluative orientation) and the perceived prevailing norms (normative orientation) on the preference of goals for the "non-conform caregivers". This subsample is characterized by a strong discrepancy between normative and evaluative orientation. The same regression analyses were done as described above for this subsample in regard to the normative and evaluative cultural orientation (see Table 5).

Individual-oriented developmental goals. Similar to the analysis of the total sample, normative orientation had a negative impact on preferences of individual-oriented goals, $\beta=-.35, p<.05$ (see Table 5). The two slopes for the interaction "culture $\times$ evaluative orientation" pointed in different directions but neither of them was significant (Brazil: $\beta=-.27, t=1.47$, $n s$; Germany: $\beta=.00, t=0.05, n s$ ). In contrast to the total sample, no differences between Brazilian and German caregivers occurred. This means that the non-conform Brazilian caregivers are more strongly affected by the perceived collectivist orientation than the total sample of Brazilian caregivers.

Group-oriented developmental goals. Similar to the analysis of the total sample, normative orientation had a positive impact on preferences of group-oriented goals, $\beta=.35, p<.001$ (see Table 5) and the two slopes for the interaction "culture $\times$ evaluative orientation" pointed in different directions. The predictive value was marginally significant for Brazilian caregivers (Brazil: $\beta=.37, t=1.73, p<.10$; Germany: $\beta=-.04, t=0.22$, $n s)$. The evaluative cultural orientation tends to be more predictive for nonconform Brazilian than for non-conform German caregivers.

Achievement-oriented developmental goals. Similar to the analysis of the total sample, neither normative orientation, $\beta=11, n s$, nor evaluative orientation, $\beta=.02$, ns, had a general impact on the preference of achievement-oriented goals (see Table 5) and the two slopes for the interaction "caregiver $\times$ normative orientation" yielded a similar pattern as for the total sample: The normative orientation is predictive for mothers, $\beta=.69, t=3.75$, $p<.001$, but not for teachers, $\beta=-.22, t=1.19, n s$ (see Table 5). 
TABLE 5

Hierarchical regression of individual cultural orientations on preference of developmental goals for non-conform caregivers

\begin{tabular}{|c|c|c|c|c|c|c|c|c|c|}
\hline & \multicolumn{3}{|c|}{ Individual-oriented goals } & \multicolumn{3}{|c|}{ Group-oriented goals } & \multicolumn{3}{|c|}{ Achievement-oriented goals } \\
\hline & $\overline{R^{2}}$ & $\Delta R^{2}$ & $\beta$ & $\overline{R^{2}}$ & $\Delta R^{2}$ & $\beta$ & $\overline{R^{2}}$ & $\Delta R^{2}$ & $\beta$ \\
\hline $\begin{array}{l}\text { Step } 1 \\
\text { Culture } \\
\text { Status of Caregiver }\end{array}$ & .30 & .30 & $\begin{array}{l}.54^{* * * 1} \\
.08\end{array}$ & .09 & .09 & $\begin{array}{l}-.18 \\
-.23\end{array}$ & .27 & .27 & $\begin{array}{c}-.51^{* * *} \\
.10\end{array}$ \\
\hline $\begin{array}{l}\text { Step } 2 \\
\quad \text { Normative orientation } \\
\text { Evaluative orientation }\end{array}$ & .43 & $.13^{* *}$ & $\begin{array}{l}-.35^{*} \\
-.12\end{array}$ & .22 & $.13^{* * *}$ & $\begin{array}{c}.35^{* * * *} \\
-.13\end{array}$ & .28 & .01 & $\begin{array}{l}.11 \\
.02\end{array}$ \\
\hline $\begin{array}{l}\text { Step } 3 \mathrm{a}^{1} \\
\quad \text { Culture } \times \text { Normative orientation } \\
\text { Culture } \times \text { Evaluative orientation }\end{array}$ & .47 & $.04^{+}$ & $\begin{array}{c}.12 \\
-.36^{+}\end{array}$ & .29 & $.07^{+}$ & $\begin{array}{l}-.20 \\
.43^{+}\end{array}$ & .29 & .01 & $\begin{array}{l}.03 \\
.14\end{array}$ \\
\hline $\begin{array}{l}\text { Step } 3 \mathrm{~b} \\
\text { Caregiver } \times \text { Normative orientation } \\
\text { Caregiver } \times \text { Evaluative orientation }\end{array}$ & .45 & .02 & $\begin{array}{r}.14 \\
-.21\end{array}$ & .25 & .03 & $\begin{array}{l}.25 \\
.14\end{array}$ & .42 & $.14^{* *}$ & $\begin{array}{l}-.55^{* *} \\
.10\end{array}$ \\
\hline
\end{tabular}

Note: ${ }^{2} 0=$ Brazil, $1=$ Germany; ${ }^{\mathrm{h}} 0=$ teachers, $1=$ mothers; 'Step 3a: $\beta=.24, n s .{ }^{+} p<.10 ;{ }^{*} p<.05 ;{ }^{* *} p<.0 \mathrm{~J} ;{ }^{* * *} p<.001$. 


\section{DISCUSSION}

The aim of this study was to test commonalities and cultural differences in regard to developmental goals between German and Brazilian kindergarten teachers and mothers of 5-year-old children and to explain individual differences by taking the status of the caregiver, the self-construal, personal values, as well as perceived cultural norms into account. The results of the study showed differences of goal preferences as well as differences of interdependent self-construal and cultural norm orientation. Altogether, intercultural differences were stronger compared to intracultural differences between mothers and teachers. The functional analysis showed that Brazilian and German caregivers, primarily mothers, orient their developmental goals toward the perceived cultural norms rather than toward their personal evaluation of these norms. Teachers show a similar pattern but also take their personal beliefs (here self-construal and evaluative orientation) into account.

\section{Cultural norms at the individual level}

A main goal of this study was to measure the individual representation of some cultural characteristics. This strategy allowed us to test whether the studied samples represented the expected culture-specific features at the group level (see Triandis, 1995). At the same time, intracultural variation can be taken into account because not all subjects may share the same cultural norms and beliefs. This approach was critically discussed by Heine, Lehman, Peng, and Greenholtz (2002). They argued that existing cultural differences might not be detected because subjects might use intracultural points of reference for their ratings.

Here, we assessed individual differences in self-construal, evaluation of cultural norms and perceived cultural norms to explain inter- and intracultural variations at the individual level. The comparisons of the self-construal scales confirmed Hypothesis 1 . The expected differences were found for the interdependence of the self-construal (Hypothesis 1). Brazilian caregivers showed a higher interdependent self-construal. No differences occurred for the independent self-construal. This result might be explained by the fact that the Brazilian sample lives in an industrialized and modernized region. Especially in larger cities, values of modernity are combined with traditional orientations. A Western-oriented lifestyle goes hand in hand with the importance of the social in-group, especially the (extended) family (see Kâgitçibâsi, 2005). Furthermore, the Brazilian as compared to the German caregivers perceived their respective society to share rather collectivist norms.

In general, the expected cultural differences could be confirmed empirically at the group level. These findings are in line with Triandis' (1995) assumption and do not speak in favour of Heine et al.'s (2002) critical 
assumption mentioned above. We also obtained similar culture-specific differences for Korean, Brazilian, and German caregivers in regard to allocentrism (Friedlmeier, Trommsdorff, Vasconcellos, Schäfermeier, 2006).

Interestingly, the majority of caregivers in both cultural groups personally held a more collectivist orientation than they perceived to prevail in the society in general. Such a strong personal collectivist orientation may be typical for the population of caregivers: The responsibility for the child and the goal to have the child adapt well to the society (including the peer group) may shift personal goals towards a more collectivist orientation compared to other societal groups.

\section{Development goals}

This study provides evidence for the relevance of cultural patterns for developmental goal preferences that confirm Hypothesis 2: German caregivers emphasized individual-oriented developmental goals more than Brazilians, but no differences occurred for group-oriented goals. The stronger individualistic orientation of Germans as compared to the Brazilians (e.g., Merritt, 2000) might explain such a greater preference of individual-oriented goals. We used a forced-choice procedure for measuring the preference of developmental goals. Presenting each goal by asking for a rating on 5- or 7-point scales may lower the differences between the goals. However, none of the caregivers had any difficulties in ranking the five selected goals. Furthermore, the results are in line with other cross-cultural studies that showed similar preferences for individual- and group-oriented goals based on individualistic vs. collectivist cultural backgrounds (Chao, 1995; Harwood, 1992). Brazilian caregivers showed a higher preference for achievement-oriented goals than German caregivers. The high importance of school entrance examinations in Brazil as well as the general economic situation of the country may lead to a stronger concern for such goals (see Furnham et al., 1996).

No intracultural differences occurred for the three sets of developmental goals. Even the extent of emphasis on achievement-oriented goals was shared between professional and non-professional caregivers within both cultural groups. This intracultural stability strengthens the assumption that differences in general cultural norms at the aggregate level may affect such preferences more than personal experiences in the child-rearing process or professional training (Goodnow, 1988). Differences only occurred for single goals: German and Brazilian mothers compared to the teachers evaluated the goals "responsibility" and "discipline" higher. It can be assumed that the preference for these goals is linked to expectations of help with household-tasks. It is also possible that the teachers may have more developmentally appropriate expectations as these goals might expect too 
much of 5-year-olds. Also, some intracultural effects were found within the Brazilian sample: Brazilian mothers ranked "autonomy" and "ability to interact" lower as compared to the teachers. "Ability to interact" seemed to be a key term for Brazilian teachers who focused on the social adaptation to others. The higher preference for "autonomy" by Brazilian teachers may be related to the fact that the promotion of autonomy has been explicitly incorporated into recent educational legislation on children's education, as mentioned in the introduction.

\section{Relations between cultural norms and developmental goals}

The caregivers' perceived cultural norms were most predictive for preferences of individual- and group-oriented developmental goals. These effects were also confirmed for the subsample of non-conform caregivers. It seems that caregivers of both cultural groups take the cultural expectations in their child-rearing more into account than their personal values. Their task is to rear the children in order to foster the development of qualities and attitudes needed for their expected roles as functioning members of their society. Even when caregivers do not agree with these general cultural norms, their goal preferences seem to be influenced by the norms of the culture that they are living in.

This effect clearly occurred for mothers across all three sets of goals. The picture looks somewhat different for kindergarten teachers. Their preference of individual-oriented goals is guided by the normative cultural orientation similar to the group of mothers. However, their preference of grouporiented goals is also related to their independence. Strong independence reduces the preference of group-oriented goals. For achievement-oriented developmental goals, an opposite relation for mothers and teachers occurred: In contrast to mothers, the more that teachers perceived the cultural norm as collectivist, the less they prefer achievement-oriented goals. It remains an open question why the effect of normative cultural orientation on preference of achievement-related goals differs so strongly. Finally, a negative effect of interdependence occurred for achievement-oriented goals for all caregivers. This result points to an interesting within-group pattern. Brazilians showed higher interdependent self-construal and higher preference for achievement-oriented goals compared to the German caregivers. However, within both cultural groups, those who are very interdependent seem to focus less on achievement-oriented goals.

\section{Methodical shortcomings and future research}

The interesting finding of the effect of perceived cultural norms on goal preferences is weakened by the rather low consistency of the Cultural 
Orientation Scales (COS). Such low alpha values often occur in crosscultural research when applying instruments in "new" cultural groups. Despite the low alpha values, none of them showed significant differences between the two cultural groups, so that a bias based on substantial differences of internal consistency can be excluded here (van de Vijver \& Leung, 1997).

The analyses of non-conform caregivers is of great interest when testing the effect of perceived norms and personal values. The group was rather small in this study. Future studies may increase the sample size.

Context variables as well as the socioeconomic level were controlled in order to provide equivalence between the two samples. The teachers' working conditions, the families' economic background, and the equipment of the kindergarten were comparable between both samples. The Brazilian and German sample represented middle-class families. Some authors argue for the treatment of socioeconomic status itself as a cultural category. This approach is adequate if the socioeconomic situation between two cultural groups is completely different (e.g., comparing German and Cameroonian samples; see Keller, Voelker, \& Yovsi, 2005). However, for the comparison between German and Brazilian caregivers, there is a social middle class in Brazil whose living condition is comparable to Germany, although the percentage is much smaller. As a consequence, the generalization of the findings is reduced, because the middle class does not represent the majority of the Brazilian society (see Ribeiro, Sabòia, Branco, \& Bregman, 1998) in contrast to the German society. A study with teachers and mothers in public kindergarten in Brazil may have resulted in stronger differences within the same society as compared to the intercultural comparison done here. Due to the stronger heterogeneity in regard to the living conditions in Brazil as compared to Germany the generalization of the results is further limited.

To conclude, the specific contribution of this study highlights that the perception of cultural norms guide caregivers' goal preferences in a stronger way than their own personal value orientations. The theoretical implications may be taken into account by future studies in this field. As the caregivers' developmental goals influence the development of the child (Cote \& Bornstein, 2003; Goodnow, 1988; Holden \& Buck, 2002; Sigel et al., 1992) and thereby his or her personality we can expect that in the case of successful transmission of these goals to the children, the present cultural norms and the related goal preferences are indirectly mediated to the next generation. 


\section{REFERENCES}

Aiken, L. S., \& West, S. G. (1991). Multiple regression: Testing and interpreting interactions. Newbury Park, CA: Sage.

Benedict, R. (1934). Patterns of culture. Boston: Houghton Mifflin.

Bierbrauer, G., Meyer, H., \& Wolfradt, U. (1994). Measurement of normative and evaluative aspects in individualistic and collectivistic orientations. In U. Kim, H. C. Triandis, C. Kâgitçibâsi, S.-C. Choi, \& G. Yoon (Eds.), Individualism and collectivism: Theory: method, and application (pp. 200-210). Thousand Oaks, CA: Sage.

Bornstein, M. H., \& Cote, L. R. (2003). Cultural and parenting cognitions in acculturating cultures 2. Patterns of prediction and structural coherence. Journal of Cross-cultural Psychology, 34, 350-373.

Brazil. (1998). Referenciais Curriculares Nacionais para a Educação Infantil [National curriculum recommendations for children's education]. Brasilia, Brazil: Ministério da Educação e do Desporto/Secretaria de Educação Fundamental.

Brazil. (1999). Diretrizes Curriculares Nacionais para a Educafão Infantil [National curriculum for children's education]. Brasilia, Brazil: Diário Oficial da União, Ministério da Educação/ Conselho Nacional de Educação.

Chao, R. (1995). Chinese and European American cultural models of the self reflected in mothers' child-rearing beliefs. Ethos, 23, 328-354.

CIA. (2005a). The world factbook (Retrieved 8 March 2006 from: http://www.cia.gov/cia/ publications/factbook/fields/2004.html).

CIA. (2005b). The world factbook (Retrieved 8 March 2006 from: http://www.cia.gov/cia/ publications/factbook/fields/2172.html).

CIA. (2005c). The world factbook (Retrieved 8 March 2006 from: http://www.cia.gov/cia/ publications/factbook/docs/notesanddefs.html/2047).

Cialdini, R. B., Wosinska, W., Barrett, D. W., Butner, J., \& Gornik-Durose, M. (1999). Compliance with a request in two cultures: The differential influence of social proof and commitment/consistency on collectivists and individualists. Personality and Social Psychology Bulletin, 25, 1242-1253.

Cote, L. R., \& Bornstein, M. H. (2003). Cultural and parenting cognitions in acculturating cultures 1. Cultural comparisons and developmental continuity and stability. Journal of Cross-Cultural Psychology, 34, 323-349.

Friedlmeier, W. (1995). Subjektive Erziehungstheorien im Kulturvergleich [Subjective child-rearing theories in cross-cultural perspective]. In G. Trommsdorff (Ed.), Kindheit und Jugend in verschiedenen Kulturen (pp. 43-64). Weinheim, Germany: JuventaVerlag.

Friedlmeier, W., \& Schäfermeier, E. (2001, June). Relationship between caregivers' understanding and evaluation of autonomy as a child-rearing goal: A comparison between German and Brazilian teachers and mothers. Paper presented at the 31st Annual Meeting of the Jean Piaget Society in Berkeley, California.

Friedlmeier, W., Trommsdorff, G., Vasconcellos, V., \& Schäfermeier, E. (2006). Allocentrism and developmental goals: A cross-cultural comparison between Brazilian, Korean, and German caregivers. Manuscript in preparation.

Furnham, A., Kirkcaldy, B. D., \& Lynn, R. (1996). National attitudes to competitiveness, money, and work among young people. Human Relations, 47, 119-132.

Goodnow, J. J. (1988). Parents' ideas, actions, and feelings: Models and methods from developmental and social psychology. Child Development, 59, 286-320.

Goodnow, J. J.. \& Collins, W. A. (1990). Development according to parents: The nature, sources, and consequences of parents' ideas. Hillsdale, NJ: Lawrence Erlbaum Associates. Inc. 
Goodwin, R., \& Plaza, S. H. (2000). Perceived and received social support in two cultures: Collectivism and support among British and Spanish students. Journal of Social and Personal Relationships, 17, 282-291.

Gouveia. V. V., de Albuquerque, J. B., Clemente, M., \& Espinosa, P. (2002). Human values and social identities: A study in two collectivist cultures. International Journal of Psychology, 37, $333-342$.

Greenfield, P. (1994). Independence and interdependence as developmental scripts: Implications for theory, research, and practice. In P. Greenfield \& R. R. Cocking (Eds.), Cross-cultural roots of minority child development (pp. 1-37). Hillsdale, NJ: Lawrence Erlbaum Associates, Inc.

Greenfield, P., Keller, H., Fuligni, A., \& Maynard, A. (2003). Cultural pathways through universal development. Annual Review of Psychology, 54, 461-490.

Harkness, S., \& Super, C. M. (1996). Parents' cultural belief systems: Their origins, expressions, and consequences. New York: Guilford Press.

Harwood, R. L. (1992). The influence of culturally derived values on Anglo and Puerto Rican mothers' perceptions of attachment behavior. Child Development, 63 , $822-839$.

Harwood, R. L., Schölmerich, A., Ventura-Cook, E., Schulze, P. A., \& Wilson, S. P. (1996). Culture and class influences on Anglo and Puerto Rican mothers' beliefs regarding long-term socialization goals and child behavior. Child Development, 67, 2446-2461.

Heine, S. J., Lehman, D. R., Peng, K., \& Greenholtz, J. (2002). What's wrong with crosscultural comparisons of subjective Likert scales? The reference-group effect. Journal of Personality and Social Psychology, 82, 903-918.

Hofstede, G. (2001). Culture's consequences: Comparing values, behaviors, institutions and organizations across nations ( $2 \mathrm{nd}$ ed.). Thousand Oaks, CA: Sage.

Holden, G. W., \& Buck, M. J. (2002). Parental attitudes toward child-rearing. In M. H. Bornstein (Ed.), Handbook of parenting: Vol. 3. Status and social conditions of parenting (2nd ed., pp. 537-562). Mahwah, NJ: Lawrence Erlbaum Associates, Inc.

Holloway, S. (2000). Accentuating the negative: Views of preschool staff about mothers in Japan. Early Education \& Development, 11, 617-632.

Hui, C. H. (1988). Measurement of individualism/collectivism. Journal of Research in Personality, 22, 17-36.

Inglehart, R. (1997). Modernization and postmodernization: Cultural, economic and political change in 43 societies. Princeton, NJ: Princeton University Press.

Ispa, J. M. (2002), Russian child care goals and values: From Perestroika to 2001. Early Childhood Research Quarterly, 17, 393-413.

Kâgitçibâsi, C. (1996). Family and human development across cultures. A view from the other side. Mahwah, NJ: Lawrence Erlbaum Associates, Inc.

Kâgitçibâsi, C. (2005). Autonomy and relatedness in cultural context. Journal of Cross-Cultural Psychology, 20, 1-20.

Keller, H., Voelker, S., \& Yovsi, R. D. (2005). Conceptions of parenting in different cultural communities: The case of West African Nso and Northern German women. Social Development, 14, 158-180.

Kornadt, H.-J., \& Trommsdorff. G. (1984). Erziehungsziele im Kulturvergleich [Childrearing goals in cross-cultural perspective]. In G. Trommsdorfl (Ed.). Erziehungssiele. Jahrbuch für empirische Erzielnungswissenschaft (pp. 191-212). Düsseldorf, Germany: Schwann.

Kornadt, H.-J., \& Trommsdorff, G. (1990). Naive Erziehungstheorien japanischer Mütter: Deutsch-japanischer Kulturvergleich [Naive child-rearing theories of Japanese mothers: A cross-cultural comparison between Germany and Japan]. Zeitschrift für Sozialisationsforschung und Erziehungssoziologie, 10, 357-376. 
LeVine, R. A. (1977). Child-rearing and cultural adaptation. In P. H. Leiderman, S. R. Tulkin, \& A. Rosenfeld (Eds.), Culture and infancy: Variations in the human experience (pp. 15-28). New York: Academic Press.

Malinowski, B. (1966). The father in primitive psychology: New York: Norton.

Markus, H. R., \& Kitayama. S. (1991). Culture and the self: Implications for cognition, emotions, and motivation. Psychological Review; 98, 224-253.

Markus, H. R., \& Kitayama, S. (1998). The cultural psychology of personality. Journal of Cross-Cultural Psychology, 38, 63-87.

McGillicuddy-DeLisi, A. V. (1985). The relationship between parental beliefs and children's cognitive level. In I. E. Sigel (Ed.), Parental helief systems: The psychological consequences for children (pp. 7-24). Hillsdale, NJ: Lawrence Erlbaum Associates, Inc.

Mead, M. (1966). Growing up in New Guinea: A comparative study of primitive education. New York: William Morrow.

Merritt, A. (2000). Culture in the cockpit: Do Hofstede's dimensions replicate? Journal of CrossCultural Psychology, 31, 283-301.

New, R. S.. \& Richman. A. L. (1996). Maternal beliefs and infant care practices in Italy and the United States. In S. Harkness \& C. M. Super (Eds.), Parents' cultural belief systems (pp. 385-406). New York: Guilford Press.

Oerter, R., \& Oerter. R. (1995). Zur Konzeption der autonomen Identität in östlichen und westlichen Kulturen [Conception of autonomous identity in Eastern and Western cultures]. In $\mathrm{G}$. Trommsdorff (Ed.), Kindheit und Jugend in verschiedenen Kulturen (pp. 153-174). Weinheim, Germany: Juventa-Verlag.

Pearson, E., \& Nirmala, R. (2003). Socialization goals, parenting practices, and peer competence in Chinese and English preschoolers. Early Child Development \& Care, 173, 131-146.

Phalet, K., \& Claeys, W. (1993). A comparative study of Turkish and Belgian youth. Journal of Cross-Cultural Psychology, 24, 319-343.

Ribeiro, R. M., Sabòia, A. L., Branco, H. C., \& Bregman, S. (1998). Estrutura familiar, trabalho e renda [Family structure, work, and income]. In S. M. Kaloustian (Ed.), Familia brasileira: $A$ base de tudo (pp. 135-158). São Paulo, Brazil: Cortez.

Rosenthal, M. K., \& Roer-Strier, D. (2001). Cultural differences in mothers' developmental goals and ethnotheories. International Journal of Psychology, 36, 20-31.

Rothbaum, F., \& Trommsdorff, G. (in press). Do roots and wings complement or oppose one another? The socialization of relatedness and autonomy in cultural context. In J. Grusec \& P. Hastings (Eds.), The handbook of socialization (2nd ed.). New York: Guilford Press.

Schäfermeier, E. (2004). Erziehungsziele und allozentrische Orientierung im Kulturvergleich und deren Funktion für das Sozialverhalten von Vorschulkindern [Child-rearing goals and allocentric orientation and their impact on preschool childrens' social behavior in a crosscultural comparison]. Berlin, Germany: Verlag für Wissenschaft und Forschung.

Schulze, P. A., Harwood, R. L., \& Schölmerich, A. (2001). Feeding practices and expectations among middle-class Anglo and Puerto Rican mothers of 12 -month-old infants. Journal of Cross-Cultural Psychology, 32, 397-406.

Schwartz, S. H. (1990). Individualism-collectivism: Critique and proposed refinements. Journal of Cross-Cultural Psychology, 53, 185-198.

Schwartz, S. H. (1994). Beyond individualism-collectivism: New dimensions of cultural values. In U. Kim, H. C. Triandis, C. Kâgitçibâsi, S.-C. Choi, \& G. Yoon (Eds.), Individualism and collectivism: Theory, methods and applications (pp. 85-121). Thousand Oaks, CA: Sage.

Schwarz, B., Schäfermeier, E,, \& Trommsdorff, G. (2005). Relations between value orientation. child rearing goals, and parenting: A comparison of South Korean and German mothers. In W. Friedlmeier, P. Chakkarath \& B. Schwarz (Eds.), Culture and human development: The importance of cross-cultural research in the social sciences (pp. 203-230). Hove, UK: Psychology Press. 
Sigel, I. E. (Ed.). (1985). Parental belief systems: The psychologicul consequences for children. Hillsdale, NJ: Lawrence Erlbaum Associates. Inc.

Sigel, I. E., McGillicuddy-DeLisi, A. V., \& Goodnow, J. J. (1992). Parental belief srstems. The psychological consequences for children. Hillsdale, NJ: Lawrence Erlbaum Associates, Inc.

Singelis, T. M. (1994). The measurement of independent and interdependent self-construals. Personality and Social Psychology Bulletin, 20, 580-591.

Singelis, T. M., \& Brown, W. J. (1995). Culture, self, and collectivist communication: Linking culture to individual behavior. Human Communication Research, 21, 354-389.

Sinha, J. B. P., \& Verma, J. (1987). Structure of collectivism. In C. Kâgitçibâsi (Ed.). Growth and progress in cross-cultural psychology (pp. 123-129). Berwyn. PA: Swets North America.

Sixtl, F. (1967). Messmethoden der Psychologie: Theoretische Grundlagen und Probleme [Methods of measurement in psychology: Theoretical basics and prohlems]. Weinheim, Germany: Beltz.

Spiro, M. E., Kilborne, B., \& Langness, L. L. (Eds.). (1994). Culture and human nature: Theoretical papers of Melford E. Spiro. New Brunswick. NJ: Transaction Publishers.

Suizzo, M.-A. (2004). French and American mothers' child-rearing beliefs: Stimulating. responding, and long-term goals. Journal of Cross-Cultural Psychology, 35. 606-626.

Super, C. M., \& Harkness, S. (1986). The developmental niche: A conceptualization at the interface of child and culture. International Journal of Behavioral Development, 9, 545-569.

Super, C. M., \& Harkness, S. (1997). The cultural structuring of child development. In J. W. Berry (Ed.), Handbook of cross-cultural psychology (pp. 1-39). Boston: Allyn \& Bacon.

Tietze, W. (1998). Wie gut sind unsere Kindergärten? Eine Untersuchung zur pädagogischen Qualität in deutschen Kindergärten [How well are our kindergartens?' A study about the pedagogical quality in German kindergartens]. Neuwied, Germany: Luchterhand.

Triandis, H. C. (1995). Individualism and collectivism. Boulder, CO: Westview Publishers.

Triandis, H. C. (2001). Individualism and collectivism: Past, present, and future. In D. Matsumoto (Ed.), The handbook of culture and psychology (pp. 35-50). Oxford. UK: Oxford University Press.

Trommsdorff, G. (1999). Autonomie und Verbundenheit im kulturellen Vergleich von Sozialisationsbedingungen [Autonomy and closeness in cultural comparison of socialization contexts]. In H. R. Leu \& L. Krappmann (Eds.), Zwischen Autonomie und Verbundenheit: Bedingungen und Formen der Behauptung von Subjektivität (pp. 392-419). Frankfurt am Main, Germany: Suhrkamp Verlag.

Trommsdorff, G., \& Kornadt, H.-J. (2003). The cultural context of parent-child relationships. In L. Kuczynski (Ed.), Handbook of dynamics in parent-child relations (pp. 271-306). London: Sage.

Vasconcellos, V., \& Friedlmeier, W. (1994, July). Cultural values and aspects of socialization. Comparison between Brazilian and German kindergarten teachers. Paper presented at the 12 th Congress of Cross-Cultural Psychology in Pamplona, Spain.

Van de Vijver, F.. \& Leung, K. (1997). Methods and data analysis for cross-cultural research. Thousand Oaks, CA: Sage.

Whiting, B. B., \& Whiting, J. W. M. (1975). Children of six cultures: A psycho-cultural analysis. Cambridge, MA: Harvard University Press.

Yu, A., \& Yang, K. (1994). The nature of achievement motivation in collectivistic societies. In U. Kim, H. C. Triandis, C. Kâgitçibâsi, S.-C. Choi, \& G. Yoon (Eds.), Individualism and collectivism: Theory, method, and application (pp. 239-266). Thousand Oaks. CA: Sage. 